\title{
Pernicious anaemia in a young man presenting with dyspepsia
}

\author{
C. G. SEMPLE \\ M.R.C.P. \\ J. M. WILliAMSON \\ F.R.C.P. (Glasgow and Edinburgh) \\ University Department of Medicine, Glasgow Royal Infirmary and Department of Medicine, Royal Alexandra \\ Infirmary, Paisley
}

\section{Summary}

An otherwise healthy 17-year-old male presented with a 6-month history of nausea and vomiting. He was shown to have Addisonian pernicious anaemia, the treatment of which resulted in resolution of his gastrointestinal symptoms.

\section{Introduction}

Addisonian pernicious anaemia is largely a disease of the middle-aged and elderly with only $2.6 \%$ of cases diagnosed below the age of 30 years (Chanarin, 1979). Patients usually attend their physician with symptoms suggestive of anaemia or glossitis although other symptoms may become apparent on close questioning. We describe a case of pernicious anaemia in a young man presenting solely with upper gastrointestinal symptoms.

\section{Case report}

A 17-year-old man presented to a general medical out-patient clinic with a 6-month history of nausea and vomiting occurring at any time of day. Occasionally he experienced a mild epigastric ache which was usually related to retching. During the month before presentation his appetite had decreased and he had lost $4 \mathrm{~kg}$ in weight despite treatment with antacids, metoclopramide, and cimetidine. He was otherwise healthy and had not lost time from work. His mother and one brother had been treated for a peptic ulcer but there was no family history of autoimmune disease.

Physical examination was entirely negative. He looked well although he was of slender build; he was not clinically anaemic and his tongue was normal.

Investigation showed a haemoglobin concentration of $9.4 \mathrm{~g} / \mathrm{dl}$, mean cell volume $113 \mathrm{fl}$, white cell count $6.9 \times 10^{9} /$ litre, platelet count $130 \times 10^{9} /$ litre, and a macrocytic blood film. Serum vitamin B12 was less than $180 \mathrm{ng} /$ litre; serum iron, total iron binding capacity and folate were normal. A megaloblastic picture was seen on bone marrow examination.
Faecal fat excretion, xylose absorption test, and a barium meal and follow-through examination were normal. Parietal cell and intrinsic factor antibodies were absent from the serum. Gastroscopy revealed a thin mucosa with biopsies showing the appearance of atrophic gastritis. A pentagastrin test confirmed achlorhydria and examination of gastric juice failed to detect intrinsic factor. Vitamin B12 absorption (by whole body monitoring) was $6 \%$ of the administered dose without and $48 \%$ with the concomitant administration of intrinsic factor.

He responded well to vitamin B12 injection; his haemoglobin rose rapidly; nausea and vomiting settled and he gained $8 \mathrm{~kg}$ in 6 weeks.

\section{Discussion}

The presenting symptoms of this patient were confined to the gastrointestinal tract. Although this mode of presentation is rare, vitamin B12 deficiency has been shown to induce megaloblastoid changes in the rapidly dividing cells of the gastrointestinal mucosa (Faroozan and Trier, 1967) and symptoms such as anorexia, nausea, vomiting, weight loss, diarrhoea and constipation are common if specifically sought (Brown, 1946; Seaton and Goldberg, 1960).

Dyspeptic symptoms in a young man suggest the diagnosis of peptic ulceration especially when a positive family history is available. In our patient abnormal findings in a routine blood count suggested the diagnosis of pernicious anaemia which might not otherwise have been considered.

Vitamin B12 deficiency in a teenager may sometimes be due to congenital intrinsic factor deficiency (Miller et al., 1966), the production of an abnormal intrinsic factor (Katz, Lee and Cooper, 1972), or selective malabsorption of vitamin B12 at the level of the terminal ileum (Imerslund, 1960; Gräsbeck et al., 1960). However, the finding in our patient of vitamin B 12 malabsorption reversed by administration of intrinsic factor and accompanied by achlorhydria 
and chronic atrophic gastritis confirm the presence of adult type pernicious anaemia, the treatment of which resulted in complete resolution of dyspepsia.

\section{Acknowledgments}

We would like to thank Dr J. F. Adams for performing the intrinsic factor assay.

\section{References}

Brown, A. (1946) Pernicious anaemia: a clinical study of 78 cases. Glasgow Medical Journal, 27, 313.
Chanarin, I. (1979) The Megaloblastic Anaemias, 2nd edn, p. 316. Blackwell Scientific Publications, Oxford.

FAROOZAN, P. \& TRIER, J.S. (1967) Mucosa of the small intestine in pernicious anaemia. New England Journal of Medicine, 277, 553.

GRÄSBECK, R., GORDIN, R., KANTERO, I. \& KUHLBACK, B. (1960) Selective vitamin B12 malabsorption and proteinuria in young people. A syndrome. Acta medica scandinavica, 167, 289.

IMERSLUND, O. (1960) Idiopathic chronic megaloblastic anaemia in children. Acta paediatrica scandinavica, 119 (Suppl.), 1.

KATZ, M., LEE, S.K. \& COOPER, B.A. (1972). Vitamin B12 malab- $\overline{\bar{T}}$ sorption due to biologically inert intrinsic factor. New England $\vec{D}$ Journal of Medicine, 287, 425.

MilleR, D.R., BloOM, G.E., STReifF, R.R., Lobuglio, A.F. \& ஜ DIAMOND, L.K. (1966) Juvenile 'congenital' pernicious anaemia. New England Journal of Medicine, 275, 978.

SEATON, D.A. \& GoldBeRG, A. (1960) Weight loss in pernicious anaemia. Lancet, i, 1002. 